Przegląd Prawa Konstytucyjnego

--ISSN 2082-1212--------

DOI 10.15804/ppk.2017.02.15

$-\mathrm{Nr} 2(36) / 2017$

\title{
Sprawozdanie
}

\section{Ogólnopolska Konferencja Naukowa Trzydziestolecie dziatalności Trybunału Konstytucyjnego. Blaski i cienie, Łódź 25 kwietnia 2016}

W dniu 25 kwietnia 2016 r. na Wydziale Prawa i Administracji Uniwersytetu Łódzkiego odbyła się Ogólnopolska Konferencja Naukowa „Trzydziestolecie działalności Trybunału Konstytucyjnego. Blaski i cienie” zorganizowana przez Koło Naukowe Prawa Konstytucyjnego Uniwersytetu Łódzkiego pod opieką dr Anny Chmielarz-Grochal i dr. Jarosława Sułkowskiego. Konferencja została podzielona na cztery panele bez podziału tematycznego.

Jako pierwszy referat wygłosił Adam Rzetecki (UAM), który przytoczył wybrane zasady podatkowe sformułowane w swej działalności orzeczniczej przez Trybunał Konstytucyjny. Prelegent podkreślił, że stanowią one do dziś istotny element ochrony praw podatników przed nadmiernym fiskalizmem. W kolejnym wystąpieniu mgr Krzysztof Riedl (UW) dokonał analizy znaczenia uchwał TK ustalających powszechnie obowiązującą wykładnię ustaw dla orzecznictwa sądów administracyjnych po 1997 r. Swój referat podsumował stwierdzeniem, że obecnie wprawdzie uchwały te nie są formalnie wiążące to jednak siła ich argumentacji powoduje, że nadal są wykorzystywane zarówno przez doktrynę, jak i sądy administracyjne. Następny referat, wygłoszony przez mgr Marikę Jankowską (UŁ) poświęcony był problematyce wpływu orzecznictwa Trybunału Konstytucyjnego na ustawodawstwo na przykładzie instytucji tzw. zażalenia poziomego (art. $394^{2}$ k.p.c.). W związku z tematem wystąpienia prelegentka omówiła kwestie wyłącze- 
nia sędziego, ukarania świadka grzywną oraz zaskarżalności postanowienia dotyczącego nieopłaconej pomocy prawnej w postępowaniu II-instancyjnym. W kolejnym wystąpieniu Sebastian Nalazek (UWM) ocenił wpływ jaki wywiera działalność orzecznicza Trybunału Konstytucyjnego w sferze obrotu nieruchomościami rolnymi. Jego zdaniem wiele wyroków zasadniczo zmieniło stosunki jakie panowały w tym przedmiocie oraz wpłynęło na praktykę stosowania prawa. Referent wyraził jednocześnie swoje wątpliwości co do konstytucyjności projektu nowelizacji ustawy o kształtowaniu ustroju rolnego. Panel zakończył się referatem Pawła Kubackiego (UŁ), który podjął próbę zdefiniowania przesłanki moralności publicznej występującej w art. 31 ust. 3 Konstytucji. Prelegent stwierdził, że pojęcie to odnosi się do relacji międzyludzkich i jest powszechnie aprobowane w całym społeczeństwie. Wskazał również, ze jest ono wykorzystywane jako kryterium ograniczające prawa i wolności obywatelskie, dlatego powinno być powoływane przez Trybunał Konstytucyjny w ostateczności.

Panel drugi rozpoczął Marcin Biskupski (UJ), wyrażając dezaprobatę co do wyroku Trybunału Konstytucyjnego z 10 grudnia 2014 r. (K 52/13), w którym uznano, że przepisy ustawy z 21 sierpnia 1997 r. o ochronie zwierząt zakazujące praktykowania uboju rytualnego są niezgodne z zasadą wolności sumienia i religii, wyrażoną w art. 53 Konstytucji RP. Student stwierdził, że nie wszystkie formy uboju rytualnego są humanitarnym pozbawieniem życia, a ochrona zdrowia zwierząt nie powinna być ograniczana ze względu na wolność religii, która nie ma charakteru absolutnego. Następnie Małgorzata Kazulak (UW) przytoczyła przykłady kontrowersyjnych jej zdaniem orzeczeń Trybunału Konstytucyjnego dotyczących sytuacji kobiet. Prelegentka omówiła między innymi wyrok, w których Trybunał uznał za zgodne z Konstytucją przepisy różnicujące wiek emerytalny kobiet i mężczyzn oraz orzeczenie, w którym uznał za niezgodne $\mathrm{z}$ ustawą zasadniczą przepisy o obowiązku lekarzy do informowania o placówkach, w których kobieta mogłaby dokonać przerwania ciąży, w wypadku powołania się przez lekarza na klauzulę sumienia. W kolejnym wystąpieniu mgr Daniel Knaga (UŁ) omówił zasadę domniemania konstytucyjności. Referent podkreślił, że utrata mocy obowiązującej norm uznanych za niekonstytucyjne następuje z datą ogłoszenia wyroku Trybunału Konstytucyjnego w Dzienniku Ustaw, jednak już sam fakt ogłoszenia wyroku przez Trybunał, po przepro- 
wadzeniu postępowania kontrolnego, nie jest pozbawiony prawnego znaczenia. Zdaniem prelegenta od momentu publicznego ogłoszenia wyroku następuje uchylenie domniemania konstytucyjności kontrolowanego przepisu. Panel zakończył referat Karoliny Kiejnich (UAM), która przedstawiła wypracowane przez orzecznictwo Trybunału Konstytucyjnego standardy prawa do nauki na uczelniach wyższych oraz granice dopuszczalności pobierania opłat za „niektóre usługi edukacyjne” w rozumieniu art. 70 ust. 2 Konstytucji RP. Studentka podkreśliła, że odpłatność za studia wieczorowe i zaoczne nie stanowi bariery w dostępie do nauki, wręcz przeciwnie rozszerza ofertę usług edukacyjnych. Referentka podsumowała swoje wystąpienie stwierdzeniem, że dopuszczalne jest pobieranie opłat tylko za usługi inne niż podstawowe, a ich nakładanie na studentów nie może mieć arbitralnego charakteru.

W kolejnym panelu Klaudia Dąbrowska (UMK) odnosząc się do wyroków Trybunału Konstytucyjnego w sprawach K 18/04 oraz K 32/09 uznała, że normy prawa pierwotnego, na które składają się traktaty zawierane przez państwa członkowskie, z prawnego punktu widzenia są umowami międzynarodowymi i podlegają ogólnemu reżimowi kontroli konstytucyjności ratyfikowanych umów międzynarodowych. Zdaniem prelegentki kognicja ta obejmuje również umowy międzynarodowe wchodzące w skład systemu prawa wspólnotowego, które zostały zawarte jeszcze przed przystąpieniem Polski do Unii Europejskiej. Następnie Oktawia Braniewicz (UMK) przedstawiła problematykę granic kontroli operacyjnej w świetle wyroku Trybunału Konstytucyjnego z 30 lipca 2014 r. (K 23/11). Referentka wskazała, że jakakolwiek ingerencja w prawa i wolności jednostek, nawet ta prowadzona w imię bezpieczeństwa narodowego, winna mieć realne podstawy normatywne, które de facto nie mogą przyznawać władzy publicznej nieograniczonych możliwości kontrolowania życia prywatnego obywateli. W kolejnym wystąpieniu mgr Paweł Króliczek (UŚ) dokonał analizy orzecznictwa Trybunału Konstytucyjnego w sprawach inicjowanych skargą konstytucyjną w kontekście funkcji trybunalskiej aquis. Prelegent podkreślił, że ustrojodawca nie sprecyzował kto jest uprawniony do wniesienia skargi konstytucyjnej, jaki jest jej przedmiot oraz podstawa, pozostawiając w tym zakresie sądowi konstytucyjnemu możliwość wypracowania własnych zasad. Następnie Paweł Śmiałek (UWM) omówił instytucję wywłaszczenia w świetle 
orzecznictwa Trybunału Konstytucyjnego, podzielając pogląd, że „cel (interes) publiczny” należy rozumieć jako dobro ogółu, a pojęcie „słusznego odszkodowania" powinno łączyć się z wartością nieruchomości. W ostatnim wystąpieniu panelu Patryk Wysocki (UŁ) podkreślił rolę zasady sprawiedliwości społecznej na działalność demokratycznego państwa prawnego. Student wskazał, że zgodnie z dyrektywami tej zasady organy władzy publicznej powinny traktować podmioty praw prywatnego o jednakowej cesze tak samo.

Ostatni panel konferencji rozpoczął Witold Pawelski (UŁ), który omówił rozbieżności w orzecznictwie Sądu Najwyższego oraz Trybunału Konstytucyjnego w kwestii uchylenia immunitetu sędziom sądów wojennych, podzielając stanowisko TK, że ofiary stanu wojennego mają prawo dochodzić swych roszczeń, a immunitet nie może być wykorzystywany w celu legalizowania bezprawnych działań. W kolejnym wystąpieniu Nikola Jadwiszczak (UKSW) przedstawiła genezę kryzysu konstytucyjnego. Jako sposób wyjścia z impasu zaproponowała opublikowanie i stosowanie orzeczeń TK, co pozwoli na przywrócenie stanu zgodnego z ustawą zasadniczą. Stanowisko studentki podzielił mgr Marcin Szwed (UW), który wskazał, że publikacja wyroku jest konieczna do wywołania przez niego skutku w postaci derogacji przepisów uznanych za niekonstytucyjne. Referent uznał, że po ogłoszeniu wyroku, a przed jego publikacją następuje utrata domniemania konstytucyjności kwestionowanych regulacji, co powinno skutkować odmową ich zastosowania przez sądy powszechne i administracyjne. Następnie Zuzanna Skowronek (UŚ) dokonała analizy uchwał Sejmu z punktu widzenia formalistycznego i realistycznego. Prelegentka uznała, że Trybunał Konstytucyjny w postanowieniu z 7 stycznia 2016 r. (U 8/15) powinien objąć swoją kognicją uchwały Sejmu, mają one bowiem normatywny charakter - zawierają normy generalno-abstrakcyjne. Kolejna referentka mgr Renata Czyżewska (UMCS) rozważała możliwość zmiany powiększenia składu Trybunału Konstytucyjnego jako remedium na zażegnanie kryzysu konstytucyjnego, dochodząc do wniosku, że zmiana liczby sędziów TK powinna być dokonana wyłącznie $\mathrm{w}$ razie pojawienia się potrzeby poprawy wydajności orzeczniczej, nie może mieć natomiast charakteru gry politycznej. Ostatnią prelegentką była Katarzyna Grabarczyk (UŁ), która omówiła problematykę kosztów sądowych w orzecznictwie Trybunału Konstytucyjnego, podkreślając, że granicą swo- 
body ustawodawcy przy kształtowaniu procedury sądowej jest treść prawa do sądu (art. 45 ust. 1 Konstytucji RP), w szczególności zapewnienie stronom uprawnień procesowych stosownie do przedmiotu prowadzonego postępowania.

Konstytucja RP z 2 kwietnia 1997 r. przyznała Trybunałowi Konstytucyjnemu szczególne zadania i kompetencje, które mają na celu zabezpieczać stabilność systemu ustrojowego oraz zapewniać obywatelom gwarancję ochrony ich konstytucyjnych praw i wolności. Poprzez kontrolę norm prawnych z punktu widzenia ich zgodności z ustawą zasadniczą Trybunał wskazuje ustawodawcy granice działalności prawodawczej wyznaczonych Konstytucją, której przestrzeganie stanowi fundament stabilności ustrojowej i prawnej państwa. Konferencja miała na celu stworzenie miejsca dyskusji nad dotychczasowym dorobkiem orzeczniczym Trybunału oraz jego wpływu na ustawodawstwo, ze szczególnym uwzględnieniem sytuacji prawnej obywateli.

Daniel Knaga Uniwersytet Łódzki 